FOLIA POMERANAE UNIVERSITATIS TECHNOLOGIAE STETINENSIS

Folia Pomer. Univ. Technol. Stetin., Oeconomica 2018, 342(90)1, 59-70

\title{
PORÓWNANIE SPÓŁEK WYBRANEGO SEKTORA NOTOWANYCH NA GIEŁDZIE PAPIERÓW WARTOŚCIOWYCH W WARSZAWIE
}

\section{COMPARISON OF COMPANIES OF A CHOSEN SECTOR LISTED ON WARSAW STOCK MARKET}

Katedra Analizy Systemowej i Finansów, Zachodniopomorski Uniwersytet Technologiczny w Szczecinie, ul. Klemensa Janickiego 31, 71-270 Szczecin, e-mail: beata.szczecinska@zut.edu.pl

\begin{abstract}
Summary. The aim of the study is to try to evaluate of the financial condition of enterprises in the selected economy sector and on this basis determine their competitive position in Poland in 2016. In the first stage of research, twelve financial indicators were calculated for each company, which were a preliminary list of diagnostic features for further research. Using the parametric method, these features were reduced to seven, which formed the basis for constructing a taxonomic measure of development. The measure was used to analyse and classify companies from the clothing and footwear sector in terms of financial situation. The survey covered nineteen companies listed on the Warsaw Stock Exchange. The results of the conducted research indicate that more than half of the surveyed enterprises has a very good and good financial situation and they are relatively stable and competitive, also has a large potential for maintaining a similar state in the following years. The group of companies with poor financial condition is relatively small, but the managers should carefully analyze their current activity and make appropriate changes.
\end{abstract}

Słowa kluczowe: analiza finansowa, wielowymiarowa analiza porównawcza.

Key words: financial analysis, multidimensional comparable analysis.

\section{WSTĘP}

Podejmowanie właściwych decyzji co do przyszłej działalności przedsiębiorstw, przez osoby zarządzające nimi, utrudnione jest z powodu znacznej zmienności czynników zewnętrznych, którym podlegają. Systematyczna ocena finansowa przedsiębiorstw staje się jednym z zasadniczych elementów pomocnym w procesie zarządzania. Przedsiębiorstwa funkcjonujące w obecnych warunkach wymagają analiz eksponujących czynniki pobudzające wzrost efektywności gospodarowania. Analiza finansowa pozwala na ocenę efektywności wykorzystania zasobów materialnych, finansowych i ludzkich, którymi dysponuje przedsiębiorstwo oraz daje względnie porównywalne informacje finansowe. Ocena finansowa to szukanie związków przyczynowo-skutkowych między zjawiskami gospodarczymi, określanie przyczyn zmian w tych zjawiskach oraz przygotowywanie decyzji dotyczących przyszłości. Wartość praktyczna analizy finansowej zależy od właściwego ustalenia czynników wpływających na kondycję finansową przedsiębiorstwa oraz od dokładnego określenia kierunków ich oddziaływania. 
W każdym sektorze gospodarki mamy do czynienia ze zjawiskiem konkurencyjności. Pojęcie „konkurencyjność” ma w literaturze wiele definicji - trudno mówić o jednej obowiązującej. Jedną z propozycji podaje Stankiewicz (2005): „[...] konkurencyjność to zdolność do sprawnego (czyli skutecznego, korzystnego i ekonomicznego) realizowania celów na rynkowej arenie konkurencji" (s. 36). Inna popularna definicja określa konkurencyjność w ekonomii jako zdolność do osiągania sukcesu w gospodarczej rywalizacji (Kamerschen i in. 1991). Stabilna wysoka pozycja konkurencyjna jest zjawiskiem pożądanym przez przedsiębiorstwa, jednak budować ją trzeba przez wiele lat. Zależy ona od czynników wewnętrznych, które mogą być kształtowane przez decyzje kierownicze, oraz od czynników zewnętrznych, które są niestabilne i do których przedsiębiorstwo musi się dostosować. Utrzymująca się w dłuższych okresach wysoka pozycja konkurencyjna odznacza się posiadaniem lepszej od konkurencji sytuacji finansowej. Jeśli niektóre czynniki wewnętrzne i zewnętrzne wpłyną na pogorszenie pozycji konkurencyjnej przedsiębiorstwa, to jest duża szansa na to, że uda mu się przetrwać w dynamicznie zmieniającym się otoczeniu.

Celem opracowania jest próba oceny sytuacji finansowej i określenia pozycji konkurencyjnej przedsiębiorstw sektora: odzież i obuwie, notowanych na Giełdzie Papierów Wartościowych w Warszawie w 2016 roku. Realizacja celu wymagała przeprowadzenia analizy finansowej poszczególnych spółek. Obliczono wskaźniki płynności, zadłużenia, obrotowości i rentowności, a następnie wykorzystano wybraną metodę wielowymiarowej analizy porównawczej do wyodrębnienia grup typologicznych badanych spółek podobnych pod względem sytuacji finansowej.

\section{WSKAŹNIKI SYTUACJI FINANSOWEJ}

Analiza finansowa jest narzędziem pozwalającym na najszybsze uzyskanie informacji na temat syntetycznej oceny całokształtu działalności gospodarczej jednostek organizacyjnych; jej wyniki stanowią podstawę weryfikacji słuszności decyzji podjętych w przeszłości oraz do ustalenia punktu wyjścia zamierzeń bieżących i przyszłościowych.

Badania niniejsze dotyczyły roku 2016 i obejmowały 19 spółek sektora: odzież i obuwie, notowanych na Giełdzie Papierów Wartościowych w Warszawie. Wybór spółek był uwarunkowany dostępnością danych ${ }^{1}$.

Punktem wyjścia przeprowadzonych badań było obliczenie wskaźników finansowych, które mogą być klasyfikowane z różnych punktów widzenia, jednak w literaturze przedmiotu najczęściej stosuje się podział ze względu na zawartą w nich treść. Posługując się tym kryterium, można wyodrębnić tyle grup wskaźników, ile jest obszarów badawczych, które wskaźniki te mają „obsługiwać”. Liczba tych obszarów może być różna i zależy od zakresu analizy finansowej. Najczęściej wyróżniane są następujące cztery grupy wskaźników (Bednarski 2002):

1) płynności,

2) wspomagania finansowego,

\footnotetext{
${ }^{1}$ W przypadku jednej ze spółek (Silvano Group AS) nie było możliwości obliczenia wszystkich zaproponowanych do badań wskaźników, dlatego pominięto ją w dalszych rozważaniach.
} 
3) obrotowości,

4) rentowności.

Ze względu na dużą liczbę wskaźników, które można skonstruować na podstawie dokumentów finansowych, należy dobierać je selektywnie, ponieważ różne wskaźniki mogą być źródłem podobnych informacji. Dlatego do analizy wybrano wskaźniki finansowe, które stanowiły wstępną listę cech diagnostycznych (tab. 1).

Tabela 1. Wyjściowy zestaw wskaźników finansowych (cech diagnostycznych) i ich charakter

\begin{tabular}{|c|c|c|c|}
\hline Lp. & Wskaźnik & $\begin{array}{c}\text { Obszar } \\
\text { analizy } \\
\text { finansowej }\end{array}$ & $\begin{array}{l}\text { Charakter } \\
\text { wskaźnika } \\
\text { (cechy) }\end{array}$ \\
\hline$X_{1}$ & bieżącej płynności & \multirow{2}{*}{ płynność } & nominanta \\
\hline$X_{2}$ & szybkiej płynności & & nominanta \\
\hline$X_{3}$ & ogólnego zadłużenia & \multirow{2}{*}{ zadłużenie } & destymulanta \\
\hline$X_{4}$ & pokrycia majątku trwałego zobowiązaniami długoterminowymi & & stymulanta \\
\hline$X_{5}$ & obrotowości majątku & \multirow{5}{*}{ obrotowość } & stymulanta \\
\hline$X_{6}$ & obrotowości majątku trwałego & & stymulanta \\
\hline$X_{7}$ & obrotowości majątku obrotowego & & stymulanta \\
\hline$X_{8}$ & rotacji zapasów (dni) & & destymulanta \\
\hline$X_{9}$ & czasu rozliczenia należności (dni) & & destymulanta \\
\hline$X_{10}$ & rentowności sprzedaży (ROS - return on sales) & \multirow{3}{*}{ rentowność } & stymulanta \\
\hline$X_{11}$ & rentowności majątku (ROA - return on assets) & & stymulanta \\
\hline$X_{12}$ & rentowności kapitału własnego (ROE- return on equity) & & stymulanta \\
\hline
\end{tabular}

Wskaźniki obliczone zostały na podstawie danych wyjściowych zaczerpniętych z informacji giełdowych oraz z raportów analizowanych przedsiębiorstw. Wszystkie cechy przyjęte do badania podzielono na: stymulanty, destymulanty i nominanty. Pierwsze $z$ nich to cechy diagnostyczne, które mają pozytywny (stymulujący) wpływ na rozwój badanego zjawiska, przy czym duże wartości świadczą o wyższym poziomie rozwoju, są więc wartościami pożądanymi, natomiast małe wartości są wartościami niepożądanymi. W przypadku destymulant sytuacja jest odwrotna - małe wartości są zjawiskiem pozytywnym, a duże negatywnym. Nominantami są cechy, dla których pożądane są "normalne poziomy” wielkości, przez które rozumie się najczęściej wartości z określonego przedziału liczbowego, przyjętego jako właściwy dla danej cechy. Krótką charakterystykę wskaźników, które uwzględniono w badaniu przedstawiono poniżej.

Płynność przedsiębiorstwa określa jego zdolność do regulowania bieżących zobowiązań. Jest ona ważna dla każdego podmiotu gospodarczego bez względu na to, w jakim sektorze gospodarki prowadzi działalność i na jaką skalę. Zapewnienie płynności finansowej to jeden z najistotniejszych problemów, ponieważ zależy od tego przetrwanie przedsiębiorstwa i jego dalszy rozwój (por. Sierpińka i Wędzki 1998). Najpowszechniej stosowanym miernikiem z tej grupy jest wskaźnik bieżącej płynności finansowej, który informuje o zdolności przedsiębiorstwa do regulacji zobowiązań krótkoterminowych na podstawie wszystkich aktywów obrotowych podmiotu gospodarczego. Za jego wartość optymalną uznaje się wartość wahającą się w przedziale od 1,2 do 2,0 (Gabrusewicz 2014). Nadmiernie duża lub nadmiernie mała wartość wskaźnika powinna skłonić kierownictwo firmy do zbadania 
przyczyn. Niski wskaźnik oznacza, że przedsiębiorstwo działa z dnia na dzień i że nie posiada wystarczających zasobów gotówkowych do spłacenia bieżących zobowiązań. Natomiast zbyt wysoki wskaźnik może wskazywać na niedostatecznie efektywne wykorzystanie wolnych zasobów majątkowych (Bednarski 2002).

Średnia wartość wskaźnika bieżącej płynności dla badanej grupy spółek wynosiła 4,47, czyli przewyższała ponaddwukrotnie zalecany poziom. Trzy spółki odnotowały w 2016 roku analizowany wskaźnik poniżej jedności, co może świadczyć o problemach ze spłatą zobowiązań bieżących. Utrzymywanie się takiej sytuacji w latach następnych może mieć poważne skutki dla funkcjonowania tych przedsiębiorstw.

Przyjęcie do oceny płynności finansowej przedsiębiorstwa łącznych jego aktywów bieżących zaciemnia obraz zdolności przedsiębiorstwa do wywiązywania się ze zobowiązań krótkoterminowych. Powstaje więc potrzeba wyłączenia z nich zasobów, których płynność jest opóźniona w relacji do innych aktywów. Dlatego do oceny płynności finansowej wykorzystuje się również wskaźnik szybkiej płynności. Wskaźnik ten pokazuje stopień pokrycia zobowiązań krótkoterminowych aktywami o dużym stopniu płynności. Najczęściej przyjmuje się, że jego wzorcowa wartość powinna kształtować się w przedziale 1,0-1,2 (Sierpińska i Wędzki 1998). Wysoki wskaźnik szybkiej płynności może oznaczać nieproduktywne gromadzenie środków pieniężnych na rachunkach bankowych oraz wystąpienie wysokiego stanu należności. W spółkach sektora: odzież i obuwie średnia wartość wskaźnika szybkiej płynności wynosiła 3,43. Jedenaście spośród nich, tj. prawie $60 \%$, nie osiągnęło najniższej granicy poziomu wzorcowego.

Wskaźniki wspomagania finansowego pomagają rozpoznać źródła finansowania działalności gospodarczej przedsiębiorstwa oraz majątku trwałego i obrotowego. Wskaźnik ogólnego zadłużenia informuje o tym, jaką część w całości aktywów stanowią zobowiązania ogółem, w związku z czym mierzy udział kapitałów obcych w finansowaniu majątku przedsiębiorstwa. Im mniejszy jest poziom tego wskaźnika, tym większa jest zdolność jednostki do spłaty długów. Nie można określić optymalnych wartości tego wskaźnika, którego poziom zależy w dużym stopniu od sektora, w jakim działa przedsiębiorstwo, ale należy pamiętać o tym, że przekroczenie pewnych granic może wiązać się z ryzykiem niewypłacalności jednostki. Według standardów zachodnich dobrze byłoby, aby wskaźnik ten nie przekraczał $67 \%$ - wyższy może świadczyć o utracie przez spółkę zdolności do regulowania swoich zobowiązań (Padurek i Szpleter 2012). Oznacza to, że wskaźnik ten ma charakter destymulanty. W analizowanej grupie przedsiębiorstw sektora: odzież i obuwie wskaźnik ten kształtował się średnio na poziomie $41 \%$.

Kredyty długoterminowe często zabezpieczone są przez określony majątek trwały. Jest to wymóg bardziej prawny niż finansowy, toteż do oceny poziomu zadłużenia firmy można wykorzystać wskaźnik pokrycia długu w środkach trwałych, nazywany też wskaźnikiem poziomu zadłużenia środków trwałych (relacja majątku trwałego do zobowiązań długoterminowych). Wskaźnik ten informuje o stopniu zabezpieczenia zobowiązań długoterminowych przez składniki majątku przedsiębiorstwa lub o tym, ile razy wartość netto tych składników wystarczy na pokrycie danego kredytu. Wskaźnik ten ma duże znaczenie informacyjne, zwłaszcza w przedsiębiorstwach zagrożonych upadłością (por. Bednarski 2002). 
Średni poziom tego wskaźnika dla badanych spółek w 2016 r. wynosił 28,9 i charakteryzował się dużą zmiennością (191\%). Tylko w przypadku jednej spółki majątek trwały nie wystarczał na zabezpieczenie zobowiązań długoterminowych (wskaźnik poniżej 1).

Wskaźniki obrotowości, nazywane też wskaźnikami sprawności działania, umożliwiają ocenę efektywności wykorzystania zasobów majątkowych przedsiębiorstwa. Istotą ich jest rozpatrywanie relacji między odpowiednim wskaźnikiem dynamicznym, wyrażającym przychód ze sprzedaży, a wskaźnikiem statycznym wyrażającym przeciętny stan składników majątkowych. Taka relacja nazywana jest wskaźnikiem obrotowości majątku. Efektywność wykorzystania zasobów majątkowych zależy także od ich wewnętrznej struktury, dlatego w opracowaniu obliczono także wskaźniki obrotowości majątku trwałego i majątku obrotowego (Bednarski 2002). Doświadczenia pokazują, iż sytuacją korzystną jest wysoki poziom wskaźników, ale zaznacza się przy tym, że ważny jest również sektor analizowanego przedsiębiorstwa (Gabrusewicz 2007). Analizowane spółki różniły się znacznie pod względem wartości wyszczególnionych wskaźników, o czym świadczą wysokie współczynniki zmienności, wynoszące: $71,4 \%$ w przypadku wskaźnika obrotowości majątku obrotowego, 101,4\% w przypadku wskaźnika obrotowości majątku ogółem i 157,7\% w przypadku wskaźnika obrotowości majątku trwałego.

Analiza sprawności działania przedsiębiorstw pogłębiona została poprzez obliczenie poziomu wskaźników rotacji zapasów w dniach oraz czasu rozliczenia należności. Najkorzystniejsza sytuacja jest wówczas, gdy należności są szybko inkasowane, a zapasy często odnawiane. Pożądane są więc jak najmniejsze wartości tych wskaźników, dlatego zaliczone zostały one do destymulant. Analizowana grupa przedsiębiorstw w 2016 r. inkasowała należności średnio po 39 dniach, natomiast przeciętny czas trwania jednego cyklu obrotowego zapasów wynosił aż 132 dni.

Wskaźniki rentowności wyrażają zdolność przedsiębiorstwa do generowania zysku. Wszystkie wyliczone w opracowaniu mierniki tej grupy w liczniku ujmowały wartość zysku netto. Doświadczenia pokazują, że im większe są wartości wskaźników rentowności, tym korzystniejsza jest sytuacja finansowa przedsiębiorstwa. Wskaźniki dotyczą różnych aspektów rentowności współczesnych przedsiębiorstw; ich wartości mogą być bardzo różne. Jednak uważa się, że w prawidłowo funkcjonującym przedsiębiorstwie zachowana jest następująca zależność: ROE>ROA>ROS (Zaleska 2005). Większość spółek badanego sektora (prawie 85\%) uzyskała w 2016 r. dodatni wynik finansowy netto, a najwyższy poziom wskaźników rentowności odnotowała Prima Moda S.A. Ponadto zachowana była w tej spółce podana powyżej zależność pomiędzy wskaźnikami rentowności.

Na podstawie struktury majątku i kapitału przeprowadzono wstępną analizę porównawczą badanych obiektów. Struktury majątku i kapitału analizowanych spółek w 2016 r. różnią się znacznie (ryc. 1 i 2). Największy udział majątku trwałego w aktywach zanotowała spółka Wistil (84\%), najmniejszy natomiast - Solar Company S.A. (13\%). Przedsiębiorstwa, takie jak: Wistil, Solar, Sanwil, Redan oraz Vistula, finansowały swoją działalność głównie z własnych środków, ponieważ udział ich kapitału własnego w pasywach przekraczał 80\%. Odmienna sytuacja miała miejsce w przypadku Intersport Polska S.A. W strukturze pasywów tej spółki przeważał kapitał obcy $(88 \%)$; były to głównie zobowiązania krótkoterminowe (95\% kapitału obcego). 


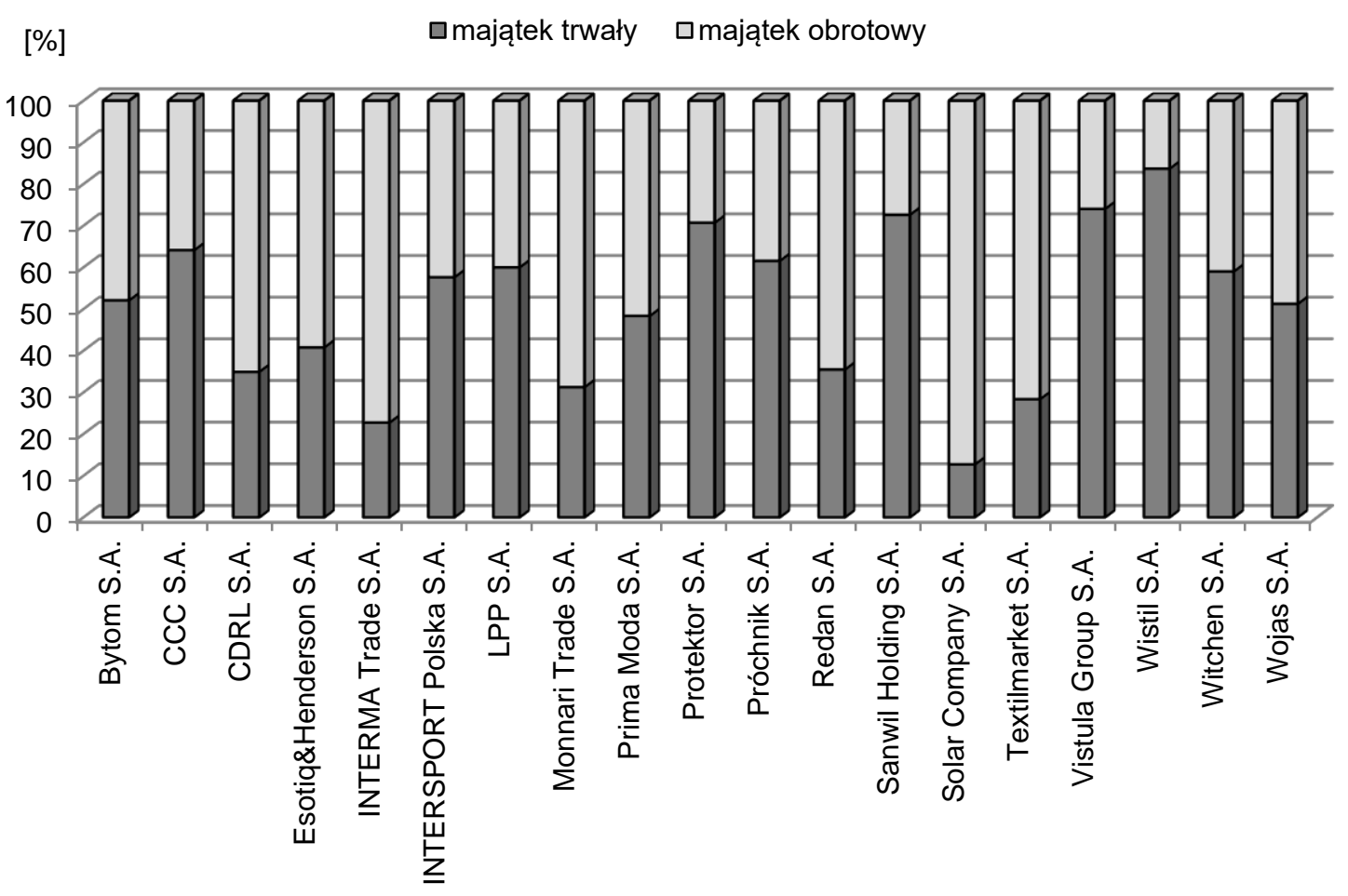

Ryc. 1. Struktura majątku badanych spółek w 2016 roku

Źródło: opracowano na podstawie danych z raportów rocznych spółek.

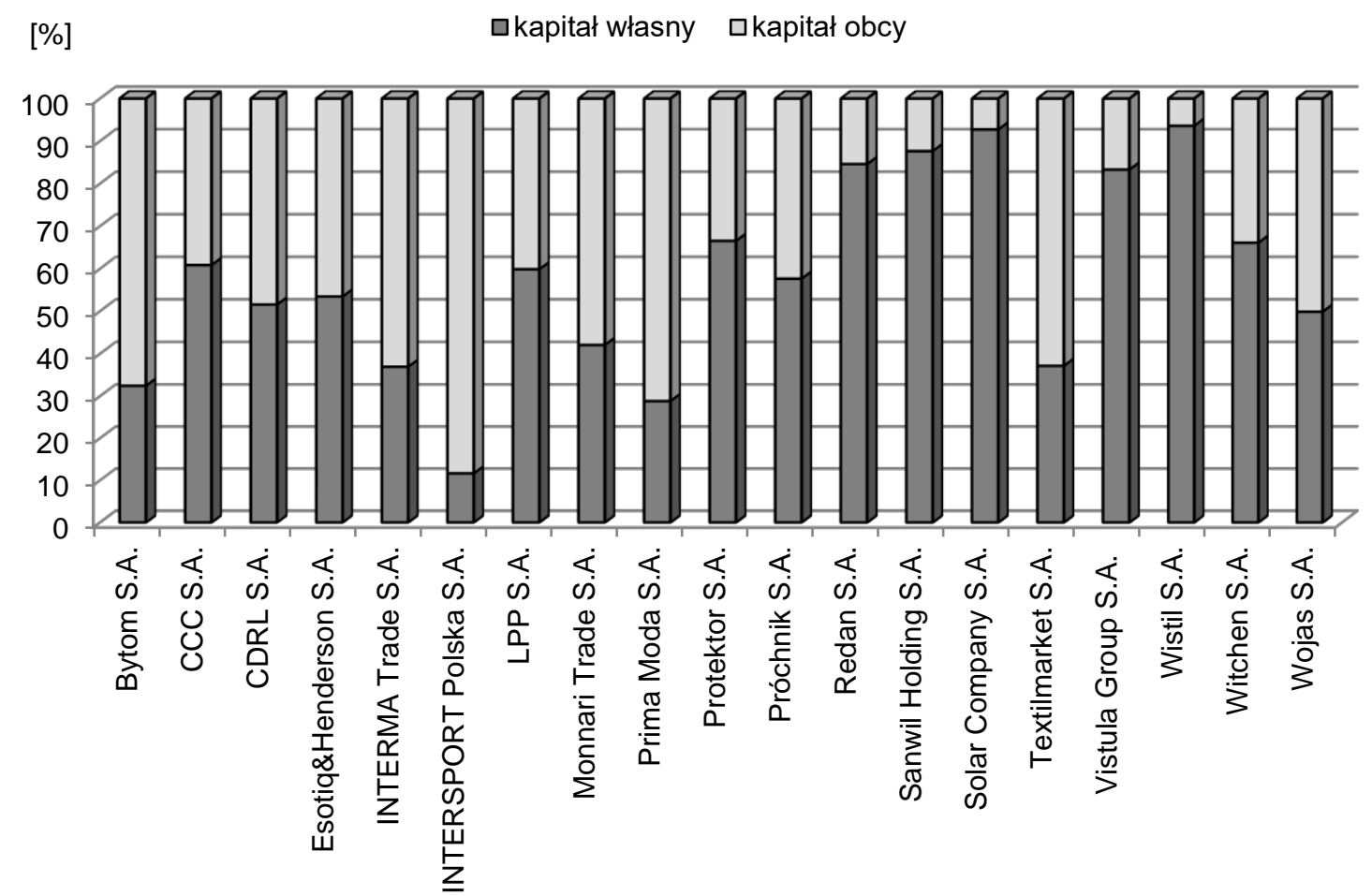

Ryc. 2. Struktura kapitału badanych spółek w 2016 roku Źródło: jak ryc. 1. 


\section{DOBÓR WSKAŹNIKÓW FINANSOWYCH DO BADAŃ}

Warunkiem uznania różnych wskaźników za cechy diagnostyczne jest ich zdolność do przeprowadzania dyskryminacji badanych obiektów. W tym celu sprawdza się, czy potencjalne cechy charakteryzują się dostatecznie dużą zmiennością, mierzoną współczynnikiem zmienności (Nowak 1990):

$$
v_{j}=\frac{s_{j}}{\bar{x}_{j}}
$$

gdzie:

$s_{j}$ - odchylenie standardowe $j$-tej cechy,

$\bar{x}_{j}-$ wartość średnia cechy $X_{j}$,

$j=1,2, \ldots, m$,

$m$ - liczba cech.

Następnie porównuje się współczynniki zmienności z arbitralnie przyjętą wartością krytyczną $v^{*}$. W badaniu przyjęto $v^{*}=10 \%$. Ze zbioru potencjalnych cech eliminuje się te wielkości, dla których:

$v_{j} \leq v^{*}$

Wszystkie przyjęte do badania cechy charakteryzowały się dużą zmiennością; ich współczynniki zmienności przyjmowały wartości od $54 \%$ do $351 \%$. Ponadto należy dodać, że charakteryzowały się one silną lub bardzo silną asymetrią.

Potencjalne cechy charakteryzujące sytuację finansową spółek mogą być ze sobą powiązane, co powoduje powielanie informacji o obiektach. Dlatego należy określić stopień skorelowania i wyeliminować te cechy, które są silnie powiązane z pozostałymi. W tym celu wyznaczono macierz współczynników korelacji pomiędzy cechami i na jej podstawie dokonano doboru cech do badania, wykorzystując metodę parametryczną zaproponowaną przez Hellwiga (Nowak 1990).

Lista cech opisujących spółki po weryfikacji formalno-statystycznej (tab. 2):

$X_{3}$ - wskaźnik ogólnego zadłużenia,

$X_{4}$ - wskaźnik pokrycia majątku trwałego zobowiązaniami długoterminowymi,

$X_{6}$ - wskaźnik obrotowości majątku trwałego,

$X_{8}$ - wskaźnik rotacji zapasów,

$X_{9}$ - wskaźnik czasu rozliczenia należności,

$X_{10}$ - wskaźnik rentowności sprzedaży (ROS),

$X_{12}$ - wskaźnik rentowności kapitału własnego (ROE).

Tabela 2. Wartości podstawowych parametrów opisowych dla przyjętych do badania cech diagnostycznych w roku 2016

\begin{tabular}{|l|r|r|r|r|r|r|r|}
\hline \multicolumn{1}{|c|}{ Cecha diagnostyczna } & \multicolumn{1}{|c|}{$X_{3}$} & \multicolumn{1}{c|}{$X_{4}$} & \multicolumn{1}{c|}{$X_{6}$} & \multicolumn{1}{c|}{$X_{8}$} & \multicolumn{1}{c|}{$X_{9}$} & \multicolumn{1}{c|}{$X_{10}$} & \multicolumn{1}{c|}{$X_{12}$} \\
\hline Średnia $\bar{x}$ & 0,406 & 28,617 & 4,311 & 131,357 & 38,694 & 0,175 & 0,116 \\
\hline Odchylenie standardowe $s(x)$ & 0,219 & 54,723 & 6,797 & 84,499 & 37,413 & 0,380 & 0,291 \\
\hline Współczynnik zmienności $V_{s}$ & 53,859 & 191,224 & 157,653 & 64,328 & 96,689 & 217,460 & 250,237 \\
\hline Wartość minimalna $x_{\min }$ & 0,064 & 0,605 & 0,019 & 0,000 & 2,113 & $-0,042$ & $-0,643$ \\
\hline Wartość maksymalna $x_{\max }$ & 0,830 & 205,188 & 31,662 & 273,134 & 136,146 & 1,645 & 1,022 \\
\hline
\end{tabular}




\section{PORZĄDKOWANIE I GRUPOWANIE SPÓŁEK}

Metody porządkowania zbioru obiektów można podzielić na metody porządkowania liniowego i nieliniowego. Pierwsze z nich pozwalają na ustalenie hierarchii obiektów ze względu na określone kryterium. Drugie natomiast służą wyłącznie do wskazania obiektów podobnych ze względu na wartości opisujących je cech (Panek 2009).

Wśród metod porządkowania liniowego można wyróżnić m.in. procedury oparte na zmiennej syntetycznej. W tym celu wykorzystuje się mierniki wzorcowe i bezwzorcowe (Pociecha i in. 1988; Grabiński 1992). W metodach bezwzorcowych zmienna syntetyczna jest funkcją znormalizowanych wartości zmiennych wejściowych. Natomiast w metodach wzorcowych wykorzystywane jest pojęcie obiektu wzorcowego, czyli obiektu modelowego o pożądanych wartościach zmiennych wejściowych. Miara syntetyczna konstruowana jest na podstawie pomiaru odległości pomiędzy obserwowanym obiektem a obiektem wzorcowym (Tarczyński i Łuniewska 2006; Panek 2009).

W opracowaniu do budowy taksonomicznego miernika rozwoju zastosowano metodę wzorcową w podejściu klasycznym. Klasyczny miernik rozwoju oparty jest na zestandaryzowanych wartościach $z_{i j}$ cech diagnostycznych, a więc (Nowak 1990):

$$
z_{i j}=\frac{x_{i j}-\bar{x}_{j}}{s_{j}},(i=1,2, \ldots, n ; j=1,2, \ldots, m)
$$

Następnie wyznacza się odległości każdego obiektu badania od ustalonego wzorca rozwoju o postaci:

$$
d_{i}=\sum_{j=1}^{m}\left|z_{i j}-\varphi_{j}\right|,(i=1,2, \ldots, n)
$$

przy czym dla symulant $\varphi_{j}=\max _{i=1,2, \ldots, n} z_{i j}$, a dla destymulant $\varphi_{j}=\min _{i=1,2, \ldots, n} z_{i j}$.

Syntetyczny miernik rozwoju wyznacza się według wzoru:

$$
\mu_{i}=1-\frac{d_{i}}{d_{0}}
$$

gdzie:

$d_{0}=\bar{d}+a S_{d}\left(\bar{d}-\right.$ średnia arytmetyczna współrzędnych wektora odległości d $\mathbf{d} S_{d}-$ ich odchylenie standardowe).

Wykorzystując formułę obliczania syntetycznego miernika rozwoju oraz informację, że przyjmuje on wartości z przedziału od 0 do 1 , określono graniczną wartość dla stałej (Tarczyński i Łuniewska 2004)2:

$$
a \geq \frac{d_{i \max }-\bar{d}}{s_{d}}
$$

gdzie:

$d_{i \max }$ - maksymalna wartość $d_{i}$,

$\bar{d}$ - średnia wartość $d_{i}$,

$S_{d}$ - odchylenie standardowe $d_{i}$.

Wartości zmiennej syntetycznej dla spółek sektora: odzież i obuwie, notowanych na Giełdzie Papierów Wartościowych w Warszawie, z uwzględnieniem przyjętych cech diagnostycznych, przedstawiono w tab. 3.

\footnotetext{
${ }^{2} \mathrm{~W}$ niniejszym opracowaniu stała $a \geq 2,3$, dlatego do obliczenia syntetycznego miernika rozwoju przyjęto $a=2,5$.
} 
Tabela 3. Liniowe porządkowanie spółek badanego sektora notowanych na GPW w Warszawie w 2016 roku

\begin{tabular}{|l|c|c|}
\hline \multicolumn{1}{|c|}{ Spółka } & Wartość miernika & Numer miejsca \\
\hline Wistil S.A. & 0,3088 & 1 \\
\hline Monnari Trade S.A. & 0,3066 & 2 \\
\hline Interma Trade S.A. & 0,2790 & 3 \\
\hline Sanwil Holding S.A. & 0,2778 & 4 \\
\hline Textilmarket S.A. & 0,2361 & 5 \\
\hline Prima Moda S.A. & 0,2249 & 6 \\
\hline CDRL S.A. & 0,2067 & 7 \\
\hline LPP S.A. & 0,2046 & 8 \\
\hline Protektor S.A. & 0,2035 & 9 \\
\hline CCC S.A. & 0,1976 & 10 \\
\hline Solar Company S.A. & 0,1951 & 11 \\
\hline Vistula Group S.A. & 0,1737 & 12 \\
\hline Witchen S.A. & 0,1683 & 13 \\
\hline Esotiq\&Henderson S.A. & 0,1209 & 14 \\
\hline Wojas S.A. & 0,1192 & 15 \\
\hline Próchnik S.A. & 0,1153 & 16 \\
\hline Bytom S.A. & 0,1123 & 17 \\
\hline Redan S.A. & 0,1056 & 18 \\
\hline Intersport Polska S.A. & 0,0147 & 19 \\
\hline
\end{tabular}

Spółka Wistil, która znalazła się na czele rankingu, charakteryzowała się najmniejszymi wartościami takich wskaźników, jak: ogólny wskaźnik zadłużenia i wskaźnik rotacji zapasów (destymulanty) oraz najwyższą rentownością sprzedaży (wartość ta była większa ponaddziewięciokrotnie od średniej dla wszystkich spółek). Ostatnie miejsca w rankingu zajmują Redan S.A. oraz Intersport Polska S.A. Przedsiębiorstwa te w 2016 r. były nierentowne i uzyskały ujemne wartości wskaźników rentowności sprzedaży oraz majątku. Ponadto charakteryzowały się niską efektywnością gospodarowania majątkiem trwałym. Spółka Intersport Polska, która znalazła się na ostatnim miejscu, miała także największe wartości wskaźników ogólnego zadłużenia oraz rotacji zapasów.

Uporządkowanie obiektów za pomocą miernika klasycznego stanowi podstawę grupowania obiektów na cztery klasy. Stosowana najczęściej metoda grupowania w ujęciu klasycznym nosi nazwę metody trzech średnich (Nowak 1990). Do ustalenia grup według tej metody stosuje się następującą formułę:

- grupa 1: $\mu_{j} \geq \bar{\mu}+S_{\mu}$,

- grupa 2: $\bar{\mu}+S_{\mu}>\mu_{j} \geq \bar{\mu}$,

- grupa 3: $\bar{\mu}>\mu_{j} \geq \bar{\mu}-S_{\mu}$,

- grupa 4: $\mu_{j}<\bar{\mu}-S_{\mu}$,

gdzie:

$\bar{\mu}$ - wartość przeciętna miernika,

$S_{\mu}$ - odchylenie standardowe miernika.

Wykorzystując metodę trzech średnich, zbiór spółek podzielono na cztery grupy obejmujące obiekty podobne pod względem badanego kryterium, czyli kondycji finansowej (tab. 4). 
Tabela 4. Wyniki grupowania spółek wybranego sektora pod względem kondycji finansowej w roku 2016

\begin{tabular}{|c|l|}
\hline Grupy & \multicolumn{1}{|c|}{ Nazwy spółek } \\
\hline I & Wistil S.A., Monnari Trade S.A., Interma Trade S.A., Sanwil Holding S.A. \\
\hline II & $\begin{array}{l}\text { Textilmarket S.A., Prima Moda S.A., CDRL S.A., LPP S.A., Protektor S.A., CCC S.A., Solar } \\
\text { Company S.A. }\end{array}$ \\
\hline III & Vistula Group S.A., Witchen S.A., Esotiq\&Henderson S.A., Wojas S.A., Próchnik S.A. \\
\hline IV & Bytom S.A., Redan S.A., Intersport Polska S.A. \\
\hline
\end{tabular}

Do grupy pierwszej zostały zaliczone przedsiębiorstwa, dla których wartość miernika syntetycznego była większa lub równa jego wartości przeciętnej, powiększonej o wartość odchylenia standardowego. Grupa ta stanowi zbiór obiektów charakteryzujących się najkorzystniejszymi wskaźnikami kondycji finansowej. Skupienie pierwsze obejmowało cztery spółki, tj. 21\% badanej zbiorowości. Charakteryzowało się największymi wartościami średnimi dla następujących stymulant: obrotowości majątku trwałego, rentowności sprzedaży oraz pokrycia majątku trwałego zobowiązaniami długoterminowymi, a także najmniejszymi wartościami przeciętnymi dwóch destymulant, tj. wskaźnika ogólnego zadłużenia oraz rotacji zapasów.

W grupie drugiej znalazły się spółki, dla których ustalony miernik klasyczny był większy lub równy jego wartości przeciętnej i jednocześnie mniejszy od sumy wartości przeciętnej i odchylenia standardowego. Była to najliczniejsza grupa, stanowiąca $37 \%$ badanych podmiotów. Osiągała także dobre wyniki, w porównaniu ze średnimi ogólnymi, szczególnie w zakresie efektywności gospodarowania majątkiem oraz rentowności. Spółki z tej grupy mają dużą szansę do zmiany swej pozycji na lepszą w kolejnych latach.

Trzecia grupa obejmuje 5 przedsiębiorstw (26\% zbiorowości) o kondycji finansowej gorszej od przeciętnej, tj. takie przedsiębiorstwa, dla których wartość miernika syntetycznego była mniejsza lub równa jego wartości przeciętnej, pomniejszonej o odchylenie standardowe, oraz mniejsza od wartości przeciętnej miernika. Skupienie to, w porównaniu z pozostałymi grupami, charakteryzuje się najmniejszą wartością średnią wskaźnika obrotowości majątku trwałego oraz mniejszymi wartościami przeciętnymi niż grupy 1 i 2 w przypadku wskaźników rentowności.

Ostatnią grupę - najmniej liczną - stanowią 3 spółki o złej kondycji finansowej. Dla nich wartość wskaźnika syntetycznego była mniejsza od wartości średniej pomniejszonej o odchylenie standardowe. Najsłabsza klasa pod względem badanego zjawiska wynika z najgorszych poziomów średnich takich cech, jak: wskaźnik rentowności sprzedaży, wskaźnik rentowności majątku, wskaźnik zadłużenia ogółem oraz rotacji zapasów.

\section{WNIOSKI}

1. Stosując parametryczną metodę Hellwiga, zredukowano wstępną listę 12 wskaźników finansowych, otrzymując 7 cech stanowiących podstawę badań. Za pomocą metody porządkowania liniowego utworzono ranking spółek notowanych na GPW w Warszawie w 2016 r. Najlepsza pod względem sytuacji finansowej okazała się spółka Wistil, która znalazła się na pierwszym miejscu w rankingu. Ostatnie miejsca w rankingu zajmowały dwie nierentowne w 2016 r. spółki - Redan S.A. oraz Intersport Polska S.A. 
2. Analiza porównawcza kondycji finansowej spółek wybranego sektora, przeprowadzona za pomocą klasycznego miernika rozwoju, pozwoliła na wyodrębnienie 4 klas spółek zbliżonych pod względem badanego zjawiska. Grupa pierwsza obejmowała 4 przedsiębiorstwa o bardzo dobrej kondycji finansowej i względnie stabilnej pozycji konkurencyjnej. Spółki te mają szansę na utrzymanie takiego stanu w latach następnych. Przedsiębiorstwa stanowiące najliczniejszą drugą grupę cechują się dobrą kondycją finansową i mają duże szanse na poprawę swojej pozycji w przyszłości. Szczególnie niekorzystna jest sytuacja ostatniej grupy, skupiającej 3 spółki o złej kondycji finansowej. Zarządzający powinni dokładnie przeanalizować ich działalność i wprowadzić stosowne zmiany.

3. Wykorzystane w pracy metody okazały się przydatnym narzędziem w określaniu kondycji finansowej spółek. Jednak należy podkreślić, że analiza porównawcza przedsiębiorstw powinna być kontynuowana w kolejnych latach. Daje to możliwość zaobserwowania prawidłowości oraz stabilności w przypadku badanego zjawiska. Wyniki przeprowadzonych badań mogą być przydatne do określenia pozycji danego przedsiębiorstwa w sektorze, co może zostać wykorzystane przez zarządzających, inwestorów i akcjonariuszy.

\section{PIŚMIENNICTWO}

Bednarski L. 2002. Analiza finansowa w przedsiębiorstwie. Warszawa, PWE.

Bień W. 2005. Zarządzanie finansami przedsiębiorstwa. Warszawa, Wydaw. Difin.

Gabrusiewicz W. 2007. Podstawy analizy finansowej. Warszawa, PWE.

Gabrusewicz W. 2014. Analiza finansowa przedsiębiorstwa. Teoria i zastosowanie. Warszawa, PWE.

Grabiński T. 1992. Metody aksonometrii. Kraków, AE w Krakowie.

Kamerschen D.R., McKenzie R.B., Nardinelli C. 1991. Ekonomia. Gdańsk, [b.w.].

Kukuła K. 2000. Metoda unitaryzacji zerowanej. Warszawa, PWE.

Nowak E. 1990. Metody taksonomiczne w klasyfikacji obiektów społeczno-gospodarczych. Warszawa, PWE.

Padurek B., Szpleter M. 2012. Rachunkowość przedsiębiorstw. Cz. IV. Wrocław, Wydaw. Bożena Padurek.

Panek T. 2009. Statystyczne metody wielowymiarowej analizy porównawczej. Warszawa, Oficyna Wydaw. SGGW.

Pociecha J., Podolec B., Sokołowski A., Zając K. 1988. Metody taksonomiczne w badaniach społeczno-ekonomicznych. Warszawa, PWN.

Tarczyński W., Łuniewska M. 2006. Metody wielowymiarowej analizy porównawczej na rynku kapitałowym. Warszawa, PWN.

Sierpińska M., Wędzki D. 1998. Zarządzanie płynnością finansową w przedsiębiorstwie. Warszawa, PWN.

Stankiewicz M.J. 2005. Konkurencyjność przedsiębiorstwa. Budowanie konkurencyjności przedsiębiorstwa w warunkach globalizacji. Toruń, Dom Organizatora.

Zaleska M. 2005. Ocena ekonomiczno-finansowa przedsiębiorstwa przez analityka bankowego. Warszawa, Wydaw. SGH.

Streszczenie. Celem opracowania jest próba oceny kondycji finansowej przedsiębiorstw wybranego sektora gospodarki i wyznaczenie na tej podstawie ich pozycji konkurencyjnej w Polsce w roku 2016. W pierwszym etapie badań dla każdej spółki obliczono 12 wskaźników finansowych, które stanowiły wstępną listę cech diagnostycznych do dalszych badań. Za pomocą metody parametrycznej cechy te zostały zredukowane do 7 cech, które stanowiły podstawę skonstruowania taksonomicznego miernika rozwoju. Posłużył on do porządkowania 
i klasyfikacji spółek z sektora: odzież i obuwie pod względem sytuacji finansowej. Badaniem objęto 19 spółek notowanych na GPW w Warszawie. Wyniki przeprowadzonych badań świadczą o tym, że grupa przedsiębiorstw o bardzo dobrej i dobrej sytuacji finansowej oraz względnie stabilnej pozycji konkurencyjnej, stanowiąca ponad połowę badanej zbiorowości, ma duży potencjał, żeby utrzymać podobny stan w kolejnych latach. Grupa spółek w złej kondycji finansowej jest stosunkowo nieliczna, jednakże zarządzający powinni dokładnie przeanalizować ich dotychczasową działalność i wprowadzić stosowne zmiany. 